\title{
Divergent Paths of State-Society Relations in European and Trans-Tasman Economic Integration
}

\author{
Matthew Castle* \\ Simon Le Quesne** \\ John Leslie ${ }^{* * *}$
}

\begin{abstract}
Author details:
* PhD Candidate, Department of Political Science, McGill University, Leacock Building, 855 Sherbrooke Street West, Montreal, Quebec H3A 2T7, Canada

Email: matthew.castle@mail.mcgill.ca

** Independent Scholar, C/O Gustavsson, Dalvägen 58 A, SE-187 33 Täby, Sweden

Email: nomadictraveller@mail.com
\end{abstract}

*** Lecturer, Political Science and International Relations Programme, Victoria University of Wellington, PO Box 600, Wellington 6140, New Zealand.

Email: John.Leslie@vuw.ac.nz

\section{Corresponding author:}

Matthew Castle, Department of Political Science, McGill University, Leacock Building, 855 Sherbrooke Street West, Montreal, Quebec H3A 2T7, Canada Email: matthew.castle@mail.mcgill.ca 
ABSTRACT

Observers of transnational market integration in Europe and elsewhere tend to assume a direct relationship between economic complementarity-high levels of economic transactions between countries-and depth of integration. Economic complementarity provides greater opportunities for private actors to capture the benefits of integration and is therefore assumed to be a source of social 'demand' required for integration. This article challenges this conventional wisdom. Australia and New Zealand have achieved a level of market integration that is comparable to that in Europe. Yet, the two countries lack economic complementarity, suggesting an alternative mechanism to the one outlined above. Rather than social groups 'demanding' integration vis-à-vis policymakers' reluctance to 'supply' it, in the trans-Tasman case policymakers led integration as the source of both 'supply' and 'demand'. This observation suggests the need to question, rather than assume, the empirical sources of supply of, and demand for, efforts to coordinate economic markets transnationally.

KEYWORDS: Regionalism, Europe, Australia, New Zealand, single market, economic integration 


\section{Introduction}

Observers of transnational market integration in Europe and other regions generally assume that high levels of economic 'complementarity' - high levels of economic exchange between countries - are important, and even necessary, for deep policy coordination. Because international economic integration involves politically costly losses of national sovereignty, strong 'demand' from social and economic actors is necessary to bring it about. High levels of economic complementarity present greater possibilities to profit from reduced costs to economic exchange and, therefore, larger potential for economic and social demands for integration. This article challenges this explanation of deep market integration. It argues that social actors represent one, but not the only source of 'demand' for transnational policy coordination. Accordingly, deep market integration may coincide with low levels of economic complementarity. The article illustrates this argument with reference to economic integration between Australia and New Zealand.

Since 2004 the official goal of economic integration between Australia and New Zealand has been construction of a Trans-Tasman Single Economic Market (TTSEM) (MFAT 2005: 31). The TTSEM reflects a thirty-year process of 'deepening' economic integration in which an inclusive, but conventional, free trade agreement for goods, the Australia-New Zealand Closer Economic Relations Trade Agreement (ANZCERTA 1983), has evolved into 'deep' economic integration that seeks to create free movement for goods, services, capital and people (Australian and New Zealand Productivity Commissions 2012: 11). For observers expecting deep market integration to coincide with high levels of economic complementarity, the TTSEM presents a puzzling juxtaposition. The depth and breadth of economic policy coordination in the TTSEM is similar to the Single European Market (SEM) and greatly exceeds coordination in other integration projects such as the ASEAN Economic Community, NAFTA and Mercosur (Leslie and Elijah 2012). Yet, relatively low levels of two-way trade demonstrate that Australia and New Zealand produce and export few things to one another when compared with European Union (EU) member states, or the US, Mexico and Canada. In other words, the Australian and New Zealand economies are far less complementary than those of EU and NAFTA member states. How - and why - did Australian and New Zealand governments supply deep and deepening integration without economic and social demand for it?

This article explains the juxtaposition of deep/deepening trans-Tasman economic integration and little economic complementarity as the result of the dominant role of Australian and New Zealand policymakers in driving integration processes. Policymakers led in setting the agenda for integration. Social interest groups, particularly business groups, provided sounding boards and expert assessments for policymakers' proposals, but rarely initiated proposals for crossborder policy coordination. When they did, policymakers ignored business initiatives that did not correspond to policymakers' interests. Social and economic interests, such as businesses' desire to expand trans-Tasman trade and investment, were a lesser source of 'demand' for trans-national coordination. Overshadowing them were the interests of policymakers in economising on state capacities, consolidating public budgets and, most importantly, restructuring and reorienting the Australian and New 
Zealand economies. In short, Australian and New Zealand policymakers provided both the 'supply' of and 'demand' for trans-Tasman integration.

The article analyses the sources of 'supply' and 'demand' for trans-Tasman economic integration in two periods that stretch from the 1980s to the 2000s. The first period focuses on negotiations leading to the 1988 Review of ANZCERTA, as policymakers transformed a conventional goods FTA into an emerging single market. The second period, from the late 1990s into the 2000s, witnessed a 'relaunch' of integration, leading, among other developments, to proclamation of the TTSEM in 2004. Before examining this empirical record, the following section places transTasman developments into the context of explanations of the relationship between economic complementarity and deep/deepening economic integration.

\section{Economic Complementarity and Deep Economic Integration}

Deep integration has been associated with high levels of economic complementarity in Europe and North America, but in Australia and New Zealand, deep and deepening economic integration has taken place despite the two economies' lack of complementarities. This section explains this apparent anomaly with reference to the different roles played by state and social actors in 'supplying' and 'demanding' integration. Economic complementarity created an incentive for social actors to 'demand' integration in Europe and North America. In Australia and New Zealand, the main source of 'demand' was not social, but governmental.

Before examining how explanations portray 'demand' for and 'supply' of policy coordination in integration however, it is important to address the comparison of the SEM and TTSEM that underlies this paper. The question of whether and how European integration might be compared to that in other regions - referred to by comparative regionalists as the ' $n=1$ ' problem (Breslin and Higgott 2000; De Lombaerde 2011; De Lombaerde et al. 2009; Leslie and Elijah 2012; Sbragia 2008; Warleigh-Lack and Rosamond 2010) — has been problematic for observers of European integration since its beginnings. The analytical value of the trans-Tasman relationship lies in both its strong similarities with and its marked departures from European experience. Trans-Tasman integration resembles European experience in at least two important ways: 1) Australasian policymakers chose a 'single market' as the format for economic integration; and 2) they constructed supra-national institutions to govern trans-Tasman markets. Australasian policymakers emulated the SEM in constructing the TTSEM (Leslie 2014). For three decades they observed Europe as an example of how to reduce barriers to the free movement of goods, services, capital and people between the two countries. They drew directly on the European Court's Cassis decision in constructing the 1998 Trans-Tasman Mutual Recognition Arrangement that provides for mutual recognition not only of product standards, but also of most labour qualifications - creating trans-national labour markets that are more deeply integrated than Europe's (Leslie 2014). Like Europeans, they also recognised that supra-national institutions can facilitate 'behind-borders' integration and adopted the two generic forms of supra-nationality found in the EU: autonomous international agencies and pooled sovereignty (Moravcsik 1998, 67-8).

Australasian policymakers did not adopt European practices slavishly, however. Rather than replicating the centralisation of issue competencies in the 
European Commission, Court and Parliament, trans-Tasman institutions decentralise supra-national legislative and dispute-resolution authority in issue-specific autonomous international agencies ${ }^{1}$ and the sectoral ministerial councils of the Council of Australian Governments (COAG), where New Zealand ministers participate in qualified majority votes. In addition to the design of its supra-national institutions, the trajectory of trans-Tasman integration also diverges from European precedent. Although Australasian policymakers considered creating both customs and currency union several times, they have always rejected both options. Indeed, the overwhelming majority of Australian and New Zealand policymakers maintain that economic and political integration are and must remain distinct. Across three decades the TTSEM has remained the end of trans-Tasman integration, rather than a step on the path to 'ever closer union'.

The nascent sub-field of comparative regionalism remains deeply divided by the ' $n=1$ ' problem and whether and how European experience is relevant for other regions. Recognition of the trans-Tasman experience increases the number of cases of deep and deepening economic integration to two. This increase is small, but critical. A second case permits us to recognise that, like economic development and democratisation, processes of deep economic integration are socially embedded (Granovetter 1985). Accordingly, they cannot be understood separate from their social and historical context. Fortunately, a rich scholarly tradition of comparative historical analysis (Mahoney and Rueschemeyer 2003) provides us with a powerful set of tools with which to analyse small numbers of cases and develop concepts for the young field of comparative regionalism. Following this tradition, the present article begins to disentangle the general from the particular in terms of how state and social actors drove different processes of deep economic integration.

The logic underlying conventional explanations linking economic complementarity and deep/deepening integration is straightforward. Because coordinating policy trans-nationally (through economic integration) entails politically costly losses of sovereignty, national governments are reluctant 'suppliers' of integration. Only economies that are complementary — and, therefore, likely to realise significant material gains through integration-will generate sufficient social 'demand' to overcome policymakers' reluctance to cede sovereignty and engage in deep and deepening integration. This view transcends academic disciplines and informs arguments on opposite sides of debates about European integration. It is also found in influential efforts to compare European economic integration with integration projects elsewhere. This explanation for the roles of state and societal actors in international economic integration is cogent, but it assumes that these actors will adopt the same 'supply' and 'demand' roles in different integration projects. As the trans-Tasman example shows, this need not be the case.

Trade economist Richard Baldwin explicitly links deep and deepening integration and economic complementarity. Compared with removing at-border barriers to trade (like tariffs), Baldwin notes that removing behind-border barrierssuch as product standards, labour qualifications and government-controlled and/or

\footnotetext{
${ }^{1}$ These include the Joint Accreditation System Australia and New Zealand (JASANZ); Food Standards Australia-New Zealand; Australia New Zealand Therapeutic Products Agency (shelved November 2014). The EU also has a number of issue-specific supranational agencies, like the European Medicines Agency (EMA), which exist parallel to its 'core' institutions.
} 
cartelised production and distribution networks - is more politically challenging (Baldwin 2012, 11). ${ }^{2}$ Accordingly, "nations will only accept losses of policy autonomy that are in line with the economic and political economy gains of doing so' (Baldwin 2012, 27). Once countries transcend this threshold, however, positive feedback mechanisms may increase demand for integration from social actors and push 'deepening' integration in what Baldwin refers to as a 'juggernaut' effect. Looking to Asia, Baldwin suggests that, because the political economic gains of doing so would be modest, institutionalising Asian regionalism is likely to 'be modest in terms of sovereignty loss' (Baldwin 2012, 27). For Baldwin, European and Asian cases demonstrate a direct relationship between economic complementarity and deep integration.

This same relationship between complementarity and depth of integration animates explanations of economic integration in political science. In neofunctionalist perspectives, Europe's deepening economic integration results from the triangular relationship between member-state governments, supra-national institutions and social interest groups. In these accounts demand for integration comes from social actors, and is supplied by state actors situated primarily at the supranational level. Thus Haas suggests that '[i]ntegration proceeds most rapidly and drastically when it responds to socio-economic demands emanating from an industrial environment', particularly in the form of organised industrial, employer and employee interests $(1961,375)$. Neo-functionalist perspectives see a direct relationship between rising social 'demand' for integration, on the one hand, and deepening integration on the other, although they see no guarantee these demands will be met without supranational leadership (Lindberg and Scheingold 1970, 114).

A generation later, European 'big' business interests facing Japanese and North American competitors in global markets were portrayed as the 'demandeurs' of revived European integration (Sandholtz and Zysman 1989; Cowles 1995). Liberal inter-governmentalists, similarly motivated to explain the 'relaunch' of European integration in the mid-1980s portrayed member states, rather than supra-national institutions, as the 'suppliers' of integration. Liberal intergovernmentalism nonetheless outlines a distinct division of labour between national governments and social interest groups, and draws a direct relationship between economic complementarity and deepening integration. Moravcsik (1993) presents European integration as a two-step process. Particular and collective social interests are expressed as 'demand' for integration in a domestic process of national preference formation (Moravcsik 1993, 483-96). National governments subsequently become suppliers of integration, choosing between different institutional designs based on a cost-benefit analysis (Moravcsik 1993, 509). Deepening integration and economic complementarity are linked, since '[1] evels of economic transactions and, in particular, intra-industry trade ... are likely to lead eventually to pressure for greater delegation and pooling of sovereignty' (Moravcsik 1993, 510). Political and electoral considerations will, however, minimise transfers of sovereignty to the supranational level (Moravcsik 1993, 511).

Analysts comparing Europe's postwar experience with other efforts at transnational market integration have also focused on the relationship between

\footnotetext{
${ }^{2}$ Lloyd (2005, 253-54) similarly distinguishes between 'border', 'beyond-the-border' and 'acrossborders' measures, the latter representing the deepest level of integration.
} 
complementarity and deepening economic integration. Mattli $(1999,42)$ suggests that for economic integration to be successful, there must be significant potential for economic gains resulting from scale economies and economic complementarities. National governments will supply integration demanded by social actors, but do so reluctantly because of the potential for coordination problems. Accordingly, Mattli foresees a need for a 'benevolent leading country' to overcome coordination issues and push integration forward (Mattli 1999, 42). Mattli extends this relationship between economic complementarity and deepening integration beyond Europe.

This division of labour echoes through the growing literature comparing integration in different regions. One finds it in the distinction that scholars in this field often draw between 'regionalisation' and 'regionalism' (Hettne 2005; Hurrell 1995; Mansfield and Milner 1999; Telo 2007). Breslin and Higgott $(2000,344)$ explain that regionalisation refers to integration processes that derive 'from markets, from private trade and investment flows, and from the policies and decisions of companies'. Regionalism on the other hand is a state-led process that 'requires governments to sanction the relaxation of barriers to trade and investment or, more proactively, to facilitate the provision of incentives to investment and trade sponsorship' (Breslin and Higgott 2000,346). While scholars contributing to this literature seem reluctant to draw a direct relationship between economic complementarity and deepening integration, the distinction between regionalisation and regionalism reinforces the presumed division of labour between societal interest groups as 'demanding' and national governments as 'supplying' transnational policy coordination.

This summary is not intended to dismiss the above explanations of integration or to suggest that no relationship exists between economic complementarity and deepening integration. Rather, it is meant to warn against turning observations into assumptions. Economic complementarity may drive - and social interest groups may provide strong demands for-deepening integration. Similarly, national governments may supply integration and they may be reluctant to cede sovereignty. These actors may perform these roles, but they may also perform other roles. Indeed, several of the accounts above recognise that national governments may also be a source of demand for integration (Haas 1961, 368; Moravcsik 1993, 491-4), or that private demand may need to be stimulated (Breslin and Higgot 2000, 346). Further, observers of transnational policy networks and policy analysts, more generally, recognise that private actors may be active in supplying policy, including trans-national policy coordination (Slaughter 2004). Rather than assume that actors play certain roles, comparative analysis must investigate empirically the sources of supply and demand in various efforts to coordinate markets trans-nationally.

Comparative scholarship has struggled to differentiate the idiosyncratic from the generalisable in European integration. The assumption that economic complementarity is required for deep market integration in non-European cases is indicative of this problem. Economic complementarity was a driving force in European integration (Moravcsik 1993, 510). Does this mean however that economic complementarity is a necessary, or even sufficient, cause of deepening integration, or just one factor contributing to developments in Europe? Must societal and state actors play the same 'demand' and 'supply' roles in integration processes elsewhere? This paper now turns to the roles of social interest groups and government actors in constructing the Trans-Tasman Single Economic Market. In contrast to the European 
case, governments in Australia and New Zealand played the leading role in demanding and supplying integration, while societal actors-especially businessplayed only a supporting role.

\section{Sources of 'Supply' and 'Demand' in Trans-Tasman Economic Integration}

The perspective in this paper turns the sources of 'supply' and 'demand' for integration into a question, rather than an assumption. Instead of assuming the roles of social interest groups and governments, we ask what roles these actors played empirically. One way to do this is to re-evaluate the 'supply' and 'demand' relationship. Explanations of integration above use the metaphor of supply and demand in a particular way, deriving from economists' understandings of transactions in markets for commodities. In commodity markets, transactions take place as 'clean' contracts - with neatly defined terms of fulfilment - between some actors who are clearly producers/suppliers and other who are consumers/demanders. However, contracts may also be 'incomplete' - uncertainties prevent a priori specification of all the terms of their fulfilment. Often such transactions transform into long-term and institutionalised relationships, where distinctions between producer/supplier and consumer/demander become blurred (Williamson 1985). These long-term relationships of 'incomplete' contracting provide a better analogy for relations between government and social actors in deep/deepening economic integration than do models of 'clean' contracting of commodity markets (Hawke 2012; Marks et al. 1996; Moravcsik 1993; Slaughter 2004).

This alternative conceptualisation of exchange 'relations' in integration permits a differentiated view of actors' roles that accords with some perspectives on European integration. Moravcsik suggests for instance that governments may demand integration to provide public goods (1993, 486; 491-4). For Sandholtz and Zysman (1989), the 1992 programme of European integration partly reflects European elites' 'demand' for integration in order to avoid economic dependence on an ascendant Japan in the context of relative US decline. Equally, they emphasised the role of transnational business interests in supplying integration through their involvement in elite bargaining with the European Commission and national governments. Similarly, Cowles (1995) underscores the dominance of the European Round Table of Industrialists (ERT) in setting the agenda for the 1992 programme of European integration. Cowles argues accordingly for a model of regulatory policymaking that incorporates the role of private interests. In accordance with a perspective that sees the sources of 'supply' and 'demand' for integration as an empirical question, this study evaluates the roles of business groups and government actors as sources of both demand and supply of trans-Tasman economic integration policies. It focuses on business groups - rather than other social actors - because economic policies and marketisation have a targeted effect on them and so they are more likely to transcend barriers to collective action and organise to promote their interests (Olson 1965; Lindblom 1977). As an indicator of the level of business demand for integration, the study uses data for bilateral trade and investment between Australia and New Zealand. As an indicator of governments' demand for integration the study uses time series data for public expenditure as a share of GDP for each country. To assess the role of business groups and government actors in supplying trans-Tasman economic 
integration, the study traces the process of policy coordination across two important periods: the initial period around the 1988 Five Year Review of the ANZCERTA, and the period of renewed interest in the relationship starting in the late 1990s.

Considerable interaction took place between policymakers and business interests, but it was policymakers who played the more important role.

\section{'Demand': Who Wanted What?}

After the ANZCERTA created an FTA for goods, the trans-Tasman relationship moved quickly to deep economic integration that has continued to deepen since. The 1988 ANZCERTA Review liberalised services trade, abolished anti-dumping and countervailing measures and moved toward coordination of technical standards, business law, government procurement policies and quarantine procedures. After a lull in the mid-1990s, trans-Tasman integration was relaunched; deepening behindborders integration and a single market became the official goal of policy coordination. Whose interests were deep and deepening integration meant to serve: businesses' or policymakers'? For the former, the gains from integration were important (especially in New Zealand), but the gains to the business community never produced a 'juggernaut' effect for deeper market integration. In contrast, bilateral liberalisation and policy coordination were central to policymakers' strategies for adjusting and reorienting the Australian and New Zealand economies toward global competition after the UK's 1973 accession to the European Economic Community.

Two-way trade between Australia and New Zealand was modest for most of the $20^{\text {th }}$ century. Australian exports to New Zealand in 1970 represented only $1.1 \%$ of total merchandise exports, and 3.7\% in 2012. New Zealand exports to Australia started higher (8.6\% of total exports) and gradually trended upwards, but in the $1990 \mathrm{~s}$ flat-lined around $23 \%$ and have begun to decline as New Zealand exports to Asia grow (Figure 1). New Zealand business interests may historically have had some incentive to pursue integration with Australia, but the inverse was certainly not true.

\section{[Figure 1 around here]}

Looking forward to the 1990 s and early 2000 s, there is little indication that the initial steps toward integration in the 1980s produced extra demand for trans-Tasman integration from the business sector. After an initial upswing in New Zealand exports to Australia in the 1980s, trade in both directions plateaued. From 1990 to 2005, the percentage of New Zealand merchandise exports destined for Australia increased by only $2.4 \%$. In the other direction, Australian exports to New Zealand as a percentage of total exports increased by only $1.82 \%$. The slowly rising levels of bilateral trade also did not produce a flood of bilateral investment, notwithstanding a surge of Australian investment in New Zealand in the early 2000s, a result of a period of global credit expansion. The rise in trade and investment increased businesses' stake in the trans-Tasman relationship, but growing trade with new markets in Asia, North America and Continental Europe overshadowed these interests (Figures 2a and 2b). Accordingly, businesses outside of the banks exerted little pressure for further economic integration. 


\section{[Figure 2a around here] \\ [Figure $2 b$ around here]}

Dramatic changes in the international economic environment in the 1970s motivated officials on both sides of the Tasman to place economic integration on the political agenda. The UK's accession to the European Economic Community (EEC) cut many Australian and New Zealand agricultural exporters from their principal markets, and negotiators at the GATT Tokyo Round (1979) had failed to reduce European and North American barriers to agricultural imports that might have made up for the loss. Compounded by the international economic turbulence of the 1970s, there was a perception among Australian policy makers that New Zealand's economy was near to collapse and that Australia should do something to prevent this (Andre, Payton, and Mills 2003).

As Moravcsik $(1993,492)$ suggests, one quantifiable index for government demand for integration may be the relative size of the national government. As a small country, New Zealand in particular faces a challenge to achieve economies of scale and scope in the performance of regulatory functions. To maintain regulatory standards set by wealthier countries, smaller countries' public sectors must consume a larger proportion of GDP than those of larger countries. New Zealand's relatively high public sector expenditure in the mid-1980s (Figure 3) suggests a potentially more convincing source of 'demand' for policy-coordination with Australia in the period immediately prior to the 1988 Review of CER. By coordinating with Australia, New Zealand policy-makers could hope to divest themselves of expensive regulatory functions - a policy move consistent with the market-led reforms of the Fourth Labour government (1984-1990).

\section{[Figure 3 around here]}

Indeed, the immediate crises of the 1980s coincided with changing economic orthodoxy and policymakers' strategic concerns about the post-war multilateral trading order and the prospects for producers of temperate-climate agricultural goods within it. In the 1980s Australia and New Zealand elected Labor/Labour governments that introduced sweeping neo-liberal economic reforms. Against this ideological backdrop, policymakers in both countries adapted to the shifting global economic order by opening their economies to improve competitiveness and diversify markets. In a clear example of what some scholars refer to as 'contagious' integration (Mansfield and Milner 1999; Mattli 1999), the UK's accession to the EEC prompted Australian and New Zealand policy makers to integrate with one another in order to compensate for the diversionary pressures of European integration (Andre, Payton and Mills 2003). Liberalising trade with each other was not an end in itself, but a first step toward greater openness. Closer bilateral economic relations, unilateral liberalisation and internal reform as well as geographic reorientation of trade and diplomacy towards the Asia-Pacific were regarded as complementary policies in a strategic reconceptualisation of the world and Australia's and New Zealand's place in it. Integration was a shared response to external economic forces, but the 
considerations of policymakers in the two countries were not identical. For New Zealand's policymakers, trans-Tasman integration was an explicit part of a larger strategic programme (New Zealand MFAT 1993). For Australian governments the relationship became inextricable from domestic micro-economic reforms and 'new federalism'. In both cases integration threatened economic interests and was as likely to provoke social resistance as it was to promote social demands for more of it. That neither occurred is explained by the lack of economic complementarities: neither the potential 'winners' nor 'losers' of integration had enough at stake to surmount the barriers to collective action. For policymakers facing different circumstances in each country however, integration offered a long-term strategy for economic growth.

Developments of the 1990s and 2000s confirmed the strategy of domestic adjustment, geographic reorientation and open regionalism launched by policymakers in the 1980s. In particular, rapid economic growth in Asia reinforced Australian and New Zealand policymakers' determination to participate in the region's dynamism. Policymakers in both countries continued to apply the lessons of 'supply-side' policy prescriptions to enhance competitiveness, while also beginning to view their own experience with deep economic integration as an 'asset' that they could leverage to ensure their own inclusion in the evolving regional architecture (New Zealand MFAT 1993; New Zealand MFAT 2003; Smith 1998). For business interests, developments in Asia overshadowed trans-Tasman integration. For Australian and New Zealand policymakers, Asian growth made trans-Tasman integration all the more important.

\section{'Supply' (and 'Demand'): Legislating Trans-Tasman Economic Integration}

Legislative processes provide opportunities for social interest groups to influence outcomes. Interests - like business groups - can raise issues and legislative solutions to them that they believe policymakers should (not) put on the agenda of integration. They can also lobby policymakers as to how (not) to construct policy coordination and how (not) to implement it. Such actions are attempts to influence the 'supply' of integration directly. Interest groups can also attempt to influence policymakers by changing the political or electoral costs of their policy choices. Such activities may involve efforts to influence public understanding of - and 'demand' for-integration. This section traces the legislation of trans-Tasman economic integration across two periods: from the mid-1980s to the early 1990s and from the end of the 1990s to the mid-2000s. In both periods some business groups expressed preferences for and against particular integration policies. Unless business preferences aligned with those of policymakers, however, they had little influence over outcomes.

\section{Review}

The 1988 Review of ANZCERTA transformed a broad but inclusive ('negative list') goods FTA into an open-ended relationship of behind-borders integration. The Review introduced numerous measures to integrate trade and services and to integrate or coordinate a number of regulatory processes pertaining to such issues as customs, quarantine, shipping, business law, technical barriers to trade and industry assistance. Although business interests had become more favourable (or less opposed) to transTasman integration after the introduction of CER, the concrete steps that the Review took toward 'deeper' economic integration reflect an agenda put in place by policy 
makers and, at times, defended by them against the resistance of business. Business consultations, where they occurred, were used to identify areas of greatest resistance rather than to encourage genuine agenda setting by business interests.

The original ANZCERTA itself reveals policymakers' leadership and at least some resistance by business. The decision to restrict ANZCERTA to a free trade area for goods rather than a customs union, single market, or currency union reflects divisions among policy makers as well as resistance from private interestsprincipally New Zealand manufacturers and Australian dairy producers (Andre, Payton, and Mills 2003; Mein Smith 2007; Templeton 1995). The ambitions of some policymakers to push integration further, however, found expression in ANZCERTA's Articles 12 and 22, which committed the governments to a five-year review of the Agreement and presented an agenda of other issues that might be addressed in that review.

By the end of the 1980s policymakers in both countries were receptive to deepening economic integration. Elections in 1983 and 1984 had brought Labor/Labour Parties to power in Australia and New Zealand, respectively. Adverse economic circumstances in the 1980s both internationally and in New Zealand made policy makers in both countries more open to change and 'unconventional' policy approaches, including neo-liberal ideas from abroad. Against this background Australian and New Zealand policymakers agreed at the August 1985 Canberra CER ministerial meeting to use the five-year CER review to address ' 2 nd $g e n e r a t i o n$ issues' anticipated by ANCERTA Articles 12 and 22. These included export subsidies, government purchasing, standards, labelling, trade practices legislation, taxation, company law, foreign investment, movement of people, transport, and tourism.

With ministerial support to use the 1988 review as the vehicle for deepening trans-Tasman economic integration, government officials took ownership of a process in which private actors would be consulted, but whose influence in shaping outcomes would prove limited. When the Australia-New Zealand Business Council (ANZBC) met in November 1986 to discuss the Review, its agenda had been compiled by New Zealand's Department of Trade and Industry from responses to public hearings and submissions on ' $2^{\text {nd }}$ generation issues' conducted by both countries' officials during 1985-86. ${ }^{3}$ The Review process ultimately reflected an agenda announced in June 1987 by the two Prime Ministers. This consisted of three main categories: the acceleration of removal of barriers on goods traded between the two countries, the widening the ANCERTA to liberalise trade in services, and deepening the relationship to coordinate regulatory policies. Following this Prime Ministerial impulse, the two countries' policymakers were largely in charge of negotiations.

Business lobbying did place some limits on the process: in order for the Review agreement to be accepted by societal interests, New Zealand's Health and Finance Minister David Caygill sought concessions from his Australian counterparts on export subsidies and public procurement. Yet the outcome of the 1988 Review demonstrates the limits of business influence, and the state's role in shaping the composition of business interests. After the Australian cabinet gave the green light for the removal of anti-dumping and countervailing measures in the Review, the Confederation of Australian Industries protested in the press, 'in the strongest possible terms', against a proposal on which it had not been consulted (CAI 1988). For New

\footnotetext{
${ }^{3}$ The ANZBC was itself an initiative prompted by the two governments.
} 
Zealand's part, Caygill remarked that the declining opposition of New Zealand's Manufacturers' Confederation (Manfed) to free trade with Australia had permitted the elimination of dumping and countervailing measures, which would have been impossible five years earlier. Like the ANZCERTA, the 1988 Review was a vehicle for the two governments' agendas, rather than for business interests. Although business opposition to trans-Tasman economic integration lessened in the 1980s, it was policymakers' interest in reorganising and reorienting the economies of both countries that drove integration forward.

\section{From low-point to relaunch: the late 1990s and the TTSEM proclamation}

The dramatic policy changes on both sides of the Tasman during the late 1980s produced a period of turbulence in political leadership during the 1990s. Programmes initiated under the 1988 Review (like mutual recognition) pushed integration forward but unsettled political leadership limited the emergence of new initiatives (Gerritsen and Eichbaum 1993). Consolidation of the centre-Right Howard and centre-Left Clark Governments in Australia (1996) and New Zealand (1999), respectively, created an opportunity for political leaders to reinitiate economic integration. Once again, this process reflected the motivations of policymakers in the two countries. A few business groups and individuals raised dramatic proposals to advance integration, but politicians and officials guided integration along a more incremental path to a single market. Advances toward a trans-Tasman single market would not have happened but for the desire of government actors in Australia and to an even greater extent New Zealand, to adjust to a changing world economy.

Some in the business community did express a clear wish for deeper integration. In the late 1990s the ANZBC had communicated a number of proposals for integration to officials, ranging from grander schemes such as a trans-Tasman currency union to those aimed at fine-tuning existing programmes such as the 1998 Trans-Tasman Mutual Recognition Arrangement (ANZBC 2003). It would be wrong to infer from this activity however that business interests had assumed a 'demand' role in the relationship between society and state. The ANZBC never represented the biggest interests in Australia's or even New Zealand's business community, and policymakers were not prepared to push the ANZBC's more ambitious projects. Moreover, although the ANZBC's interest in integration resulted in an invitation to attend official discussions on a relaunched integration agenda announced in 2000 by the two countries' Trade Ministers, ${ }^{4}$ policymakers maintained tight control of the process.

Indeed, ANZBC President Ross Patterson's assessment that 'business [would] drive the agenda' (Smellie 2000) was overly optimistic. Patterson would more gloomily note in 2003 that 'for the past ten years there has not been any coherent strategic plan or a way forward for CER' (ANZBC 2003). The ANZBC's failure to influence policy led to declining interest among participants and its replacement in the policy process by the Australia New Zealand Leadership Forum (ANZLF) - which like its predecessor was a creature of government officials. Officially, the ANZLF was to be business-led. In reality, the ANZLF reflected an effort by policymakers to

\footnotetext{
${ }^{4}$ The ministers announced evaluations of: country of origin regulations, business law harmonisation, a merging of stock exchanges, and triangular taxation (Sutton and Vaile 2000).
} 
promote awareness of the trans-Tasman relationship in order to advance policymakers' integration goals. Business interest was especially important for New Zealand's policymakers, who believed that without it the Australian Cabinet might lose interest in the relationship. The ANZLF also enabled policymakers to maintain control over the integration agenda. Even as they raised businesses' awareness of the trans-Tasman relationship, policymakers ensured the ANZLF's agenda was compatible with their own. Strategies to achieve this included the New Zealand government's manipulation of the ANZLF's co-chair arrangements and its invitation and agenda-setting processes. Thus, when business participants in early ANZLF meetings raised 'big ideas' to advance economic integration - a common currency, common third party free-trade agreements, visa-free reciprocal entry, a common immigration policy, more effective labour market regulatory integration, taxation reform and security and defence integration (Deane 2005) - they were successfully opposed by New Zealand's Reserve Bank, Treasury and members of the Cabinet (Cullen and Costello 2005; O’Sullivan 2004).

The agenda of government officials looked rather different to that of business groups. Officials favoured incremental changes and initiatives that enhanced government capacity and reduced public budgets. These included initiatives in the areas of food standards, regulation and procurement of therapeutic products like pharmaceuticals and medical devices (von Tigerstrom 2007) as well as deeper integration of capital markets (Cullen 2004). Far more than that of business, it is this latter agenda that would be reflected in the path that integration took. In 2004 Australian Treasurer Peter Costello and New Zealand Minister of Finance Michael Cullen announced the creation of the TTSEM, billed as 'a seamless trans-Tasman business environment' (Cullen and Costello 2004) based on the coordination of business regulation.

The single market declaration reflected limitations that both states wished to place on the relationship as much as their desire to push integration forward. Partisan differences between the Howard (Australia) and Clark (New Zealand) governments produced a mixed record of results in efforts to deepen capital market integration. The limits on integration also reflect the caution of New Zealand officials to cede too much state autonomy - as the smaller partner in the Australia-New Zealand bilateral relationship, sacrifices of sovereignty will take place disproportionately on the New Zealand side of the Tasman. So, officials in both countries decided against the harmonisation of prudential banking regulation, an Australian initiative New Zealand was not keen on. They considered - and rejected - mutual recognition of imputation/franking credits, a New Zealand initiative Australia was not keen on. They also examined common competition laws, an initiative that regulators in neither country were keen on. The two sides found common ground in easing movement of goods and people, harmonising business services - such as accounting standardsand streamlining investment and securities regulations. These advances were incremental, irregular and fell far short of the grander visions articulated by business interests.

By 2004 and the proclamation of the TTSEM, a coalition of business actors and policymakers existed to support integration. Policymakers, particularly in New Zealand, were not reluctant suppliers of this integration; they were its architects. As with the 1988 Review, it was policymakers who initiated the development toward the 
Trans-Tasman Single Economic Market. Moreover, it was policymakers who sought to activate business interests to support deeper integration. At the same time, concerns for sovereignty led New Zealand policymakers to pursue an incremental approach and set limits on economic integration where business actors sought to advance it more dramatically.

For the past decade, an incremental approach towards a 'single market' has defined the trajectory of trans-Tasman economic integration. The comparative regionalism literature helps us to understand this case as an example of state-led regionalism as opposed to regionalisation; it is a process initiated, sustained and controlled by state actors. The trans-Tasman case also however gives us insights into the state-society relationships that may underpin the distinction between regionalism and regionalisation. Economic complementarity and societal demand are inherent to regionalisation: it is by definition a market-led process (Breslin and Higgott 2000, 344). In cases of regionalism, the trans-Tasman case suggests that when other actors-like national governments - act as an alternative source of demand for deep and deepening market integration, this process may proceed without high economic complementarity. The trans-Tasman case shows that social actors need not always be the primary source of 'demand' for integration, and deep integration need not necessarily be associated with greater economic complementarity. Indeed, deep integration may contradict societal demands and, thereby, serve policymakers' 'developmental' goals.

\section{Conclusion}

Across thirty years trans-Tasman economic integration has deepened from an inclusive, but conventional, free trade area for goods to a single market comparable to the Single European Market. Two characteristics of this development distinguish it from European experience. First, deep and deepening economic integration has taken place despite relatively low social demand and relatively little complementarity between the two countries' economies. While each country's market offers growth opportunities to producers from the other, these are less important than opportunities elsewhere. Deepening economic integration despite weak demand among social interest groups, especially business, contradicts the conventional perspective that integration results from a strong social demand for it and is reluctantly supplied by government.

A second characteristic of trans-Tasman economic integration also stands out: policymakers played a leading role in both 'supplying' and 'demanding' integration. In the 1988 ANZCERTA Review process it was policymakers who placed ' 2 nd generation issues' on the agenda. They raised these issues not to meet demands from societal actors. Rather economic integration served the long-term interests that both countries' governments had in adjusting their economies to enhance openness and competitiveness.

These observations about the development of trans-Tasman economic integration provide at least two useful conceptual insights about our understanding of processes of deep and deepening economic integration. First, they remind us that while 'supply and demand' offers a useful metaphor to understand policy processes, it is a metaphor that suggests a 'clean' transactional relationship between state and 
society. In reality, the policy process may be more akin to an incomplete contract, where state and social actors do not necessarily assume fixed roles of 'seller' and 'buyer' of policy. Dominant observations of deepening economic integration have tended to assume that the exchange relationship underlying deepening integration entails a clear division between (strong) demand from societal interest groups and (reluctant) supply from national governments hesitant to cede sovereignty. This approximates Europe's experience, but trans-Tasman integration offers an empirical example in which actors have played different roles. Placing trans-Tasman processes in comparative perspective reminds us that the sources of supply and demand for deepening economic integration remain an empirical question rather than an assumption: state-society relations do not follow one logic in all contexts. This may help to explain cases where deep integration coexists with little economic complementarity.

Juxtaposing trans-Tasman and European experiences illustrates the social embeddedness of deep integration processes. For at least some of the architects of the EEC and its successor organisations, economic integration was a step toward 'closer union' and political integration and, therefore, they endowed Europe's supra-national institutions with a centralised design. For Australasian policymakers-New Zealanders in particular - economic growth was desirable, but federalism was not. Accordingly, they limited integration to a single market and decentralised supranational authority to reduce 'spill-overs' between policy areas. While it cannot resolve questions about causality, recognition of trans-Tasman experience as another case of deep economic integration permits us to begin to raise questions about the driversidiosyncratic and general-of integration. 


\section{References}

Andre, Pamela, Stephen Payton and John Mills, eds. 2003. The Negotiation of the Australia-New Zealand Closer Economic Relations Trade Agreement 1983. DFAT and MFAT Canberra: Commonwealth of Australia.

Australian Government. 1983. Australia-New Zealand Closer Economic Relations Trade Agreement. Canberra: Australian Government.

Australian Government and New Zealand Government. 1988. Agreed Documents from the 1988 Review of ANZCERTA. Wellington: New Zealand Department of Trade and Industry.

Australia-New Zealand Business Council. 2003. 'Australia and NZ Govts Should Listen to Business.' Scoop: Business 28 August. Accessed 21 September 2013. www.scoop.co.nz/stories/BU0308/S00259.htm.

Australian Productivity Commission and New Zealand Productivity Commission. 2012. Strengthening Trans-Tasman Economic Relations - A Joint Study (Final Report). Accessed 13 September 2013. www.mfat.govt.nz/downloads/foreignrelations/australia/anzcer-cep.pdf.

Baldwin, Richard E. 2012. 'Sequencing Asian Regionalism: Theory and Lessons from Europe.' Journal of Economic Integration 27(1): 1-32.

Breslin, Shaun and Richard Higgott. 2000. 'Studying Regions: Learning from the Old, Constructing the New.' New Political Economy 5(3): 333-52.

Confederation of Australian Industry (CAI). 1988. 'Anti-Dumping and CER' News Briefs 4(12) 19 August 1988 Publication No NBG 7762.

Cowles, Maria G. 1995. 'Setting the Agenda for a New Europe: The ERT and EC 1992.' Journal of Common Market Studies 33(4): 501-526.

Cullen, Michael. 2004. 'Budget 2004 Speech 27 May.' Scoop: Parliament. Accessed 21 September 2013. www.scoop.co.nz/stories/PA0405/S00572.htm.

Cullen, Michael and Peter Costello. 2004. 'Ministers Enhance the trans-Tasman Business Environment 30 January.' Scoop: Parliament. Accessed 21 September 2013. www.scoop.co.nz/stories/PA0401/S00291/ministersenhance-the-transtasman-environment.htm.

Cullen, Michael and Peter Costello. 2005. 'Joint Press Conference 18 February.' Scoop. Accessed 21 September 2013. www.scoop.co.nz/stories/PA0502/S00409/cullen-and-costello-joint-pressconference.htm.

Deane, Roderick. 2005. 'Comments on a Single Economic Market for Australia and New Zealand.' Independent Economics. Accessed 26 November 2012. www.independenteconomics.com/assets/papers/anzleadershipforum.pdf.

De Lombaerde, Phillipe. 2011. 'The Good, the Bad and the Ugly in Comparative Regionalism: A Comment on Sbragia.' Journal of Common Market Studies 49(3): 675-681.

De Lombaerde, Phillipe, Fredrik Söderbaum, Luk Van Langenhove, and Francis Baert. 2009. 'The Problem of Comparison in Comparative Regionalism.' Jean Monnet/Robert Schuman Paper Series. EUCE University of Miami.

Gerritsen Rolf and Chris Eichbaum. 1993. 'The Impossible Politics of CER? The Prospects for the ANZ Closer Economic Relations Agreement in 1993 and Beyond.' The Australian Quarterly 65(1): 516-533. 
Granovetter, Mark. 1985. 'Economic Action and Social Structure: The Problem of Embeddedness.' American Journal of Sociology 91(3): 481-510.

Haas, Ernst B. 1961. 'International Integration: The European and the Universal Process.' International Organization 15(3): 366-392.

Hawke, Gary. 2012. 'What Kind of Economic Integration?.' ERIA Research Institute Network Statement, 1. Accessed 23 October 2013. www.eria.org.

Hettne, Bjorn. 2005. 'Beyond the "New” Regionalism.' New Political Economy 10(4): 543-571.

Hurrell, Andrew. 1995. 'Explaining the Resurgence of Regionalism in World Politics.' Review of International Studies 21(4): 331-358.

Leslie, John. 2014. 'Regionalism by Diffusion and Design: Australasian Policymakers, Europe and Asian-Pacific Economic Integration.' Asia Europe Journal (firstview): 1-18. Doi: 10.1007/s10308-014-0403-9.

Leslie, John and Annmarie Elijah. 2012. 'Does N=2?: Trans-Tasman Economic Integration as a Comparator for the Single European Market.' Journal of Common Market Studies 50(6): 975-993.

Lindberg, Leon N. and Stuart A. Scheingold. 1970. Europe's Would-Be Polity: Patterns of Change in the European Community. Englewood Cliffs: PrenticeHall.

Lindblom, Charles E. 1977. Politics and Markets: The World's Political and Economic Systems. New York: Basic Books.

Lloyd, Peter J. 2005. 'What is a Single Market? An Application to the Case of ASEAN.' ASEAN Economic Bulletin 22(3): 251-265.

Mahoney, James, and Dietrich Rueschemeyer. 2003. 'Comparative Historical Analysis: Achievements and Agendas.' In Comparative Historical Analysis in the Social Sciences, ed. Mahoney and Rueschemeyer. Cambridge: Cambridge University Press, 3-38.

Mansfield, Edward D. and Helen V. Milner. 1999. 'The New Wave of Regionalism.' International Organization 53(3): 589-627.

Marks, Gary, Liesbet Hooghe, and Kermit Blank. 1996. 'European Integration from the 1980s: State-Centric v. Multi-level Governance.' Journal of Common Market Studies 34(3): 341-378.

Mattli, Walter. 1999. The Logic of Regional Integration: Europe and Beyond. Cambridge: Cambridge University Press.

Mein Smith, Philippa M. 2007. 'Did Muldoon Really “Go Too Slowly” with CER?.' New Zealand Journal of History 41(2): 161-179.

Moravcsik, Andrew. 1993. 'Preferences and Power in the European Community: A Liberal Intergovernmentalist Approach.' Journal of Common Market Studies 31(4): 473-524.

New Zealand Department of Trade and Industry. 1988. Review of ANZERTA Official Documents. Wellington: Department of Trade and Industry.New Zealand Ministry of Foreign Affairs and Trade. 1993. New Zealand Trade Policy: Implementation and Directions - A Multi-Track Approach. Wellington: MFAT.

New Zealand Ministry of Foreign Affairs and Trade. 2003. 'Trans-Tasman Mutual Recognition Arrangement', in Critical Paths in Trans Tasman Economic Relations: CER 20 th Anniversary. Wellington: MFAT. 
New Zealand Ministry of Foreign Affairs and Trade. 2005. The Australia - New Zealand Closer Economic Relationship, 2005. Accesed 18 September 2013. http://www.mfat.govt.nz/downloads/foreign-relations/australia/anzcer-cep.pdf

New Zealand Treasury. 2011. 'Government and Economic Growth: Does Size Matter?.' New Zealand Treasury Paper 11/01, April.

O'Sullivan, Fran. 2004. 'Trans-Tasman single market looking likely.' The New Zealand Herald 26 May.

Olson, Mancur. 1965. The Logic of Collective Action: Public Goods and the Theory of Groups. Cambridge, MA: Harvard University Press.

Sandholtz, Wayne and John Zysman. 1989. '1992: Recasting the European Bargain.' World Politics 42(1): 95-128.

Sbragia, Alberta. 2008. 'Review Article: Comparative Regionalism: What Might It Be?'’ Journal of Common Market Studies 46(SI): 29-49.

Slaughter, Anne-Marie. 2004. 'Disaggregated Sovereignty: Towards the Public Accountability of Global Government Networks.' Government and Opposition 39(2): 159-190.

Smith, Anthony L. 1998. 'AFTA-CER Dialogue: A New Zealand Perspective on an Emerging Trade Area Linkage.' ASEAN Economic Bulletin 14(3): 238-52.

Smellie, Pattrick. 2000. 'Singapore-New Zealand Deal a Catalyst for Wider Regional Trade Agreements', Australian Financial Review 1 September.

Sutton, Jim and Mark Vaile. 2000. 'Joint Ministerial Statement: CER Trade Ministers 31 August.' New Zealand Government Press Release. Accessed 21 September 2013. www.iatp.org/files/Joint_Statement_CER Trade_Ministers Meeting.htm.

Telo, Mario. 2007. The EU and the New Regionalism. Hampshire: Ashgate Publishing Ltd.

Templeton, Hugh. 1995. All Honourable Men: Inside the Muldoon Cabinet 19751984. Auckland: Auckland University Press.

Von Tigerstrom, Barbara. 2007. 'Globalisation, Harmonisation and the Regulation of Therapeutic Products: the Australia New Zealand Therapeutic Products Authority Project in Global Context.' Canterbury Law Review 13: 287-313.

Warleigh-Lack, Alex and Ben Rosamond. 2010. 'Across the EU Studies-New Regionalism Frontier: Invitation to a Dialogue.' Journal of Common Market Studies 48(4): 993-1013.

Williamson, Oliver E. 1985. The Economic Institutions of Capitalism: Firms, Markets, Relational Contracting. New York, London: Free Press. 
Figure 1. Australian and New Zealand two-way exports (percentage of total exports), 1970-2013

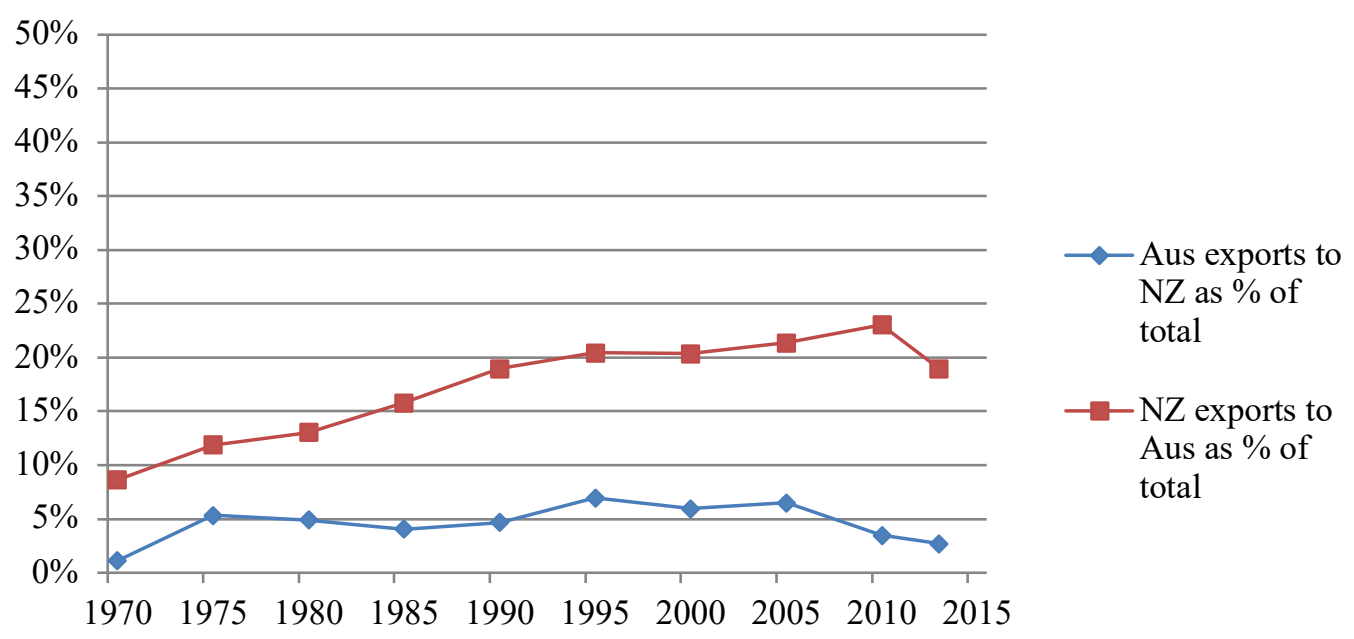

Data source: United Nations Comtrade database, DESA/UNSD

Figure 2a. Australian exports to selected trade partners as percentage of total exports, 1970-2013

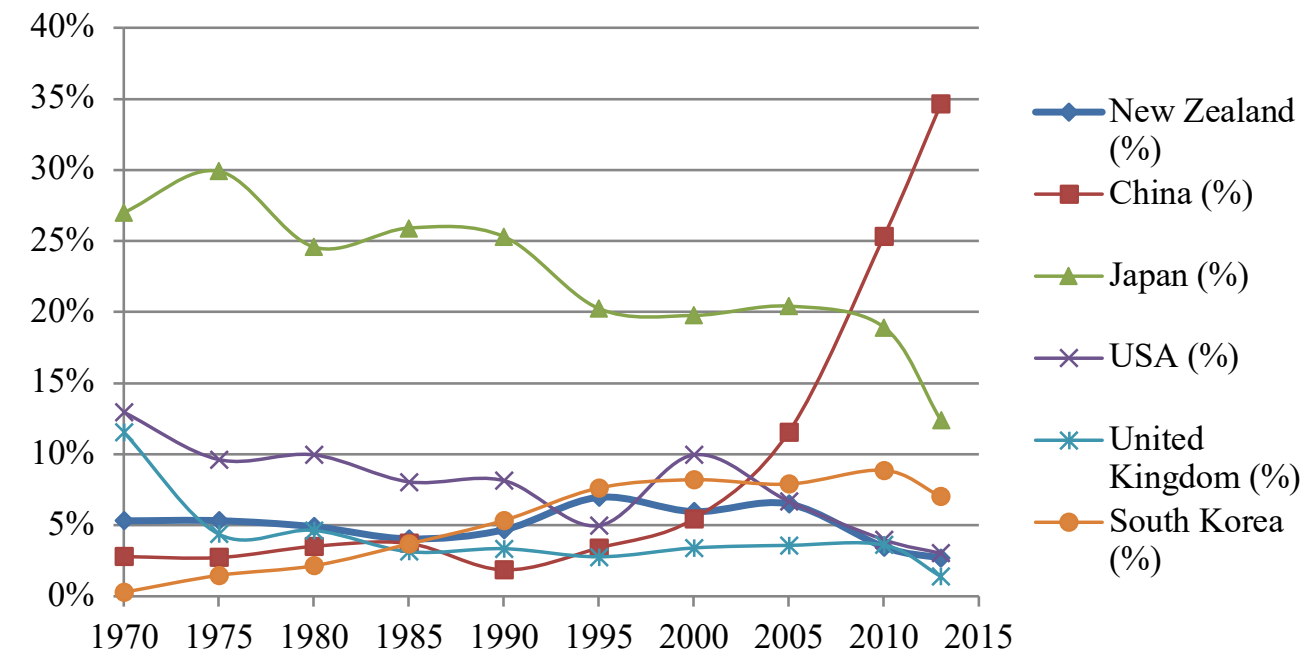

Data source: United Nations Comtrade database, DESA/UNSD 
Figure 2b. NZ exports to selected trade partners as percentage of total exports, 1970-2013

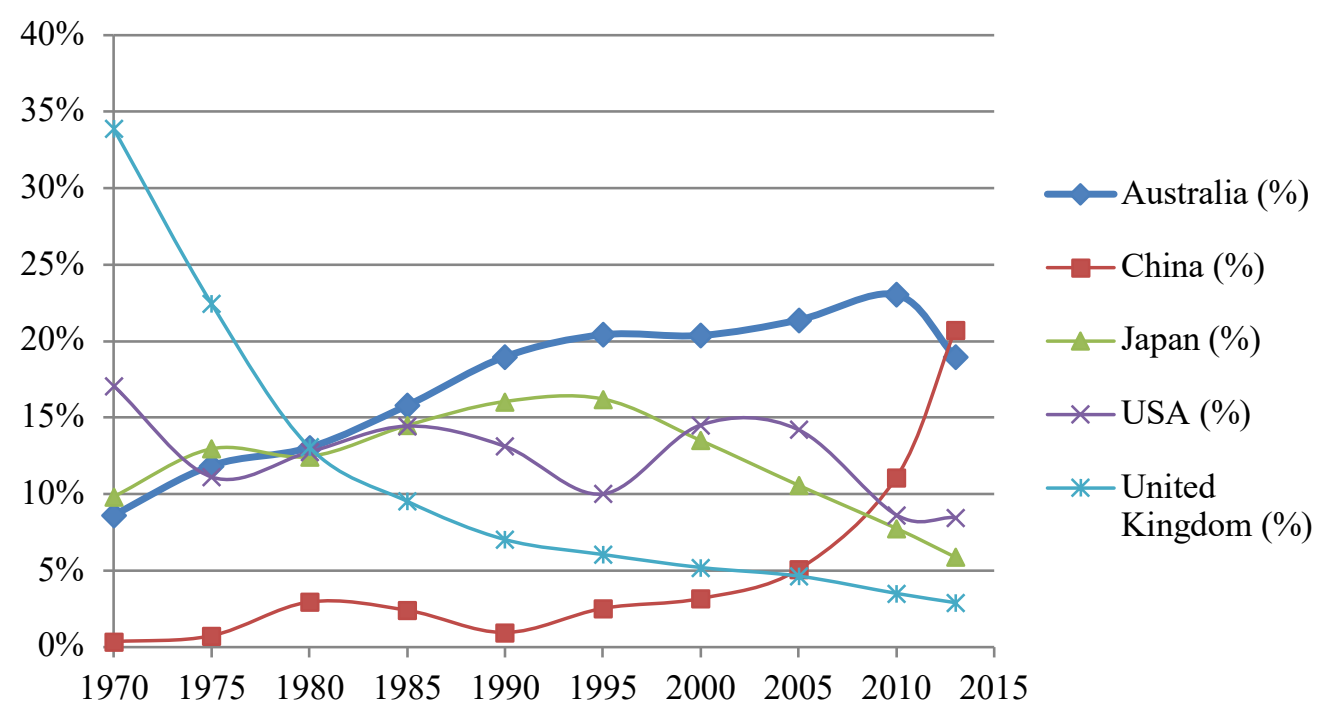

Data source: United Nations Comtrade database, DESA/UNSD

Figure 3. Australian, NZ and OECD-32 government expenditure (percentage of GDP) 1970-2010

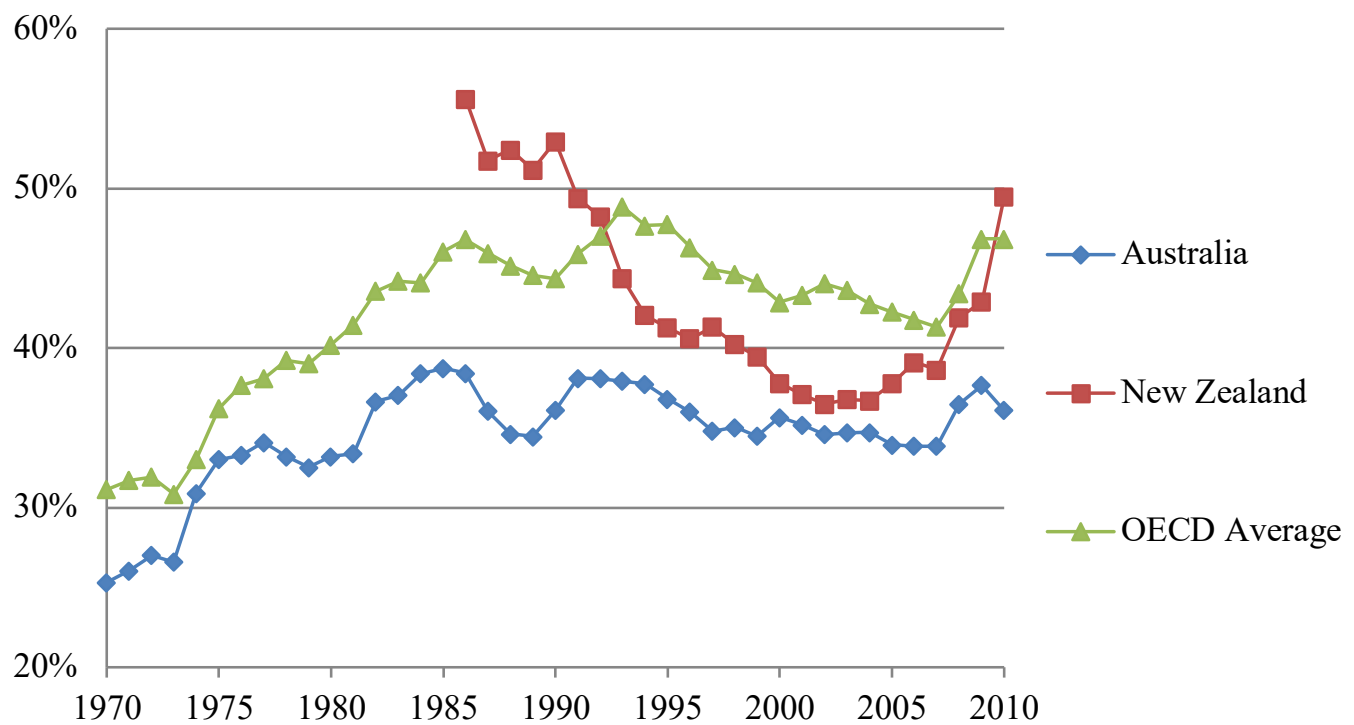

Data source: OECD Statistics 